\title{
FAKTOR - FAKTOR YANG BERHUBUNGAN DENGAN KELUHAN NYERI PUNGGUNG BAWAH PADA PEKERJA WELDING
}

\author{
Noviyanti ${ }^{1}$, Yessi Azwar ${ }^{2}$, Eva Santi ${ }^{3}$, Dwi Tegar Larasati ${ }^{4}$ \\ ${ }^{1,4}$ Program Studi S1 Kesehatan dan Keselamatan Kerja Universitas Ibnu Sina Batam \\ ${ }^{2,3}$ Program Studi D III Kebidanan Stikes Payung Negeri Pekanbaru \\ Email: noviyanti75@gmail.com
}

Diterima: Juni 2021, Diterbitkan: Juni 2021

\begin{abstract}
ABSTRAK
Nyeri punggung bawah adalah gangguan musculoskeletal yang disebabkan akibat aktifitas tubuh yang kurang baik. Faktor penyebab nyeri punggung bawah dapat berasal dari, usia, indeks massa tubuh, kebiasaan merokok, masa kerja, dan posisi kerja. Tujuan dari penelitian ini adalah untuk mengetahui faktor - faktor yang berhubungan dengan keluhan nyeri punggung bawah pada pekerja welding di PT X Kota Batam Tahun 2020. Jenis penelitian ini menggunakan deskriptif analitik dan menggunakan pendekatan kuantitatif dengan menggunakan desain Cross Sectional. Sampel dalam penelitian ini adalah pekerja bagian Welding pada PT X dengan jumlah 85 orang. Teknik pengambilan sampel dalam penelitian ini adalah Total Sampling dan analisis statistik menggunakan uji Chi-Square. Intrumen yang digunakan dalam penelitian ini adalah kuesioner dan table ceklis. Responden dengan kategori umur $\geq 35$ tahun sebanyak 48 responden $(56,6 \%)$, Responden dengan kategori IMT overweight sebanyak 35 responden $(41,2 \%)$, Responden dengan kategori merokok sebanyak 59 responden $(69,4 \%)$, Responden dengan kategori masa kerja $\geq 5$ tahun sebanyak 54 responden (36,5\%), Responden dengan kategori posisi kerja janggal sebanyak 56 responden $(65,9 \%)$. Dari hasil penelitian diperoleh adanya hubungan Faktor individu (usia, IMT, kebiasaan merokok dan masa kerja) dengan keluhan nyeri punggung bawah ( $p$ value $=0,000$ ), dan hubungan Faktor pekerjaan (posisi kerja) dengan keluhan nyeri punggung bawah $(p$ value $=0,000)$. Berdasarkan hasil penelitian maka diharapkan PT X untuk melaksanakan pemeriksaan terahadap karyawans secara rutin agar nyeri punggung pada pekerja bisa diatasi.
\end{abstract}

Kata kunci: NPB, Posisi Kerja, Peregangan Otot

\begin{abstract}
Low back pain is the musculoskeletal disorders caused by poor body activity. The purpose of this research is to know the factors related to low back pain complaints on welding workers at PT X Batam City. This type of research uses descriptive analytical and uses a quantitative approach using a cross sectional design. The sample in this study were 85 workers in the Welding section of PT X. The sampling technique in this study is Total Sampling and statistical analysis using Chi-Square test. The results of the research from 85 respodents found that 48 respondents (56,5\%) had experienced low back pain. Respondents with age category over 35 years were 48 respondents (56,6\%), Respondents with BMI category overweight were 35 respondents (41,2\%), Respondents with smoking category were 59 respondents $(69,4 \%)$, respondents with working period of more than 5 years were 54 respondents (36,5\%), Responden with awkward working position category as many as 56 respondens (65,9\%). The results of the analysis show that there is a relation between individual factors (age, BMI, smoking habit and years of work) with complaints of low back pain ( $p$-value 0,000) and a relation between job factors (working position) with complaints of low back pain (p-value 0,000). Based on the results of the study, it is expected that PT X will carry out regular checks on employees so that back pain in workers can be overcome.
\end{abstract}

Keywords: LBP, Working Position, Streching Muscle 


\section{PENDAHULUAN}

Nyeri punggung bawah atau low back pain adalah gangguang musculoskeletal yang diakibatkan oleh aktifitas tubuh yang kurang baik. Masalah nyeri punggung yang ditimbulkan karena terlalu lamanya duduk menjadi salah satu fenomena yang sering terjadi (Lukman dan Nurna Ningsih, 2012). Hal-hal yang mempengaruhi terjadinya LBP yaitu kebiasaan duduk terlalu lama serta bekerja dengan posisi membungkuk dalam waktu cukup lama. Menurut (Wijayanti, 2017) faktor-faktor yang berisiko pada keluhan nyeri punggung bawah yang dialami para pekerja yaitu: usia, indeks massa tubuh, jenis kelamin, kebiasaan merokok, masa kerja, beban kerja, durasi, posisi kerja, repetisi, dan faktor lingkungan.

Nyeri punggung pada umumnya terjadi salah satunya pada negara Inggris, di negara Inggris terdapat sekitar $60-80 \%$ orang pernah mengalami nyeri punggung bawah. Nyeri punggung baeah menjadia salah satu alasan utama untuk tidak bekerja, pada setiap tahunnya jutaan hari kerja hilang dikarenakan nyeri punggung bawah. Di Inggris dan Amerika Serikat kejadian nyeri punggung bawah telah mencapai proporsi endemik. Dari hasil survey yang telah dilakukan terdapat laporan sebanyak 17,3 juta orang Inggris mengalami nyeri punggung bawah dan 1,1 juta orang mengalami kelumpuhan yang diakibatkan nyeri punggung bawah (Septiawan, 2014).

Di Indonesia nyeri punggung bawah termasuk penyakit nomor dua pada manusia setelah influenza. Dari hasil penelitian yang dilakukan oleh Dokter Saraf Seluruh Indonesia (PERDOSSI) melaporkan bahwa sekitar 18,1\% mengalami nyeri punggung bawah (Wulandari \& Zaidah, 2019). Berdasarkan dari data pada tahun 2017, Poliklinik Rehabilitasi Medik di RSUD Embung Fatimah Batam terdapat sebanyak 4835 pasien. Dari data jumlah pasien tersebut terdapat $10 \%$ mengalami nyeri punggung bawah (Huryah \& Susanti, 2019). Dari hasil penelitian didapati sebanyak $42,6 \%$ pekerja di RS Awal Bros Batam mengalami nyeri punggung bawah (Wardhani, 2018).

PT X merupakan perusahaan yang bergerak pada bidang pembuatan dan perbaikan kapal tongkang dan tug boat. Perusahaan ini memiliki area terbuka dengan luas tanah 52 hektar. Aktivitas yang dilakukan diperusahaan ini yaitu pengecetan, pengelasan, menggerinda, pemotongan, dan lain-lain. Dari hasil survey yang dilakukan peneliti pada tanggal 09 maret 2020 didapatkan hasil sebanyak 10 orang pekerja pada bagian pengelasan melakukan pekerjanya yaitu memproduksi dan memperbaiki kapal tongkang dengan posisi tubuh pekerja rata-rata pekerja melakukan pekerjaannya dengan posisi menjongkok, sebanyak 10 pekerja yang dilakukan survey terdapat 4 pekerja melaporkan bahwa mengalami meringis serta menggosok-gosok pungung, mengalami kran pada bagian punggung serta mersakan nyeri pada punggung bagian bawah.

Berdasarkan hal tersebut peneliti tertarik untuk melakukan penelitian dengan judul skripsi mengenai "Faktor - Faktor Yang Berhubungan Dengan Keluhan Nyeri Punggung Bawah Pada Pekerja Welding Di PT X Kota Batam Tahun 2020". Tujuan penelitian ini untuk Mengetahui Faktor - Faktor Yang Berhubungan Dengan Keluhan Nyeri Punggung Bawah Pada Pekerja Welding Di PT X Kota Batam Tahun 2020.

\section{METODE PENELITIAN}

Pada penelitian ini berjenis deskriptif analitik dengan pendekatan kuantitatif dan penelitian ini termasuk kedalam desain penelitian cross sectional. Lokasi penelitian ini dilakukan di PT $\mathrm{X}$ yang bertempat di Jl. Pattimura Sei Kasam Telaga Punggur, Kelurahan Kabil, Kecamatan Nongsa, Kota Batam. Penelitian ini dilaksanakan pada bulan Juni 2020 sampai dengan Agustus 2020. Populasi dalam penelitian ini ialah karyawan subcont PT $\mathrm{X}$ dengan lebih tertuju pada pekerjaan di bidang welding yang berjumlah sebesar 85 pekerja dengan subjek penelitian ialah karyawan subcont di PT X tahun 2020. Dalam penelitian ini jumlah sample yang akan diteliti yaitu sebesar 85 pekerja di bagian welding dengan teknik sampel yaitu total sampling atau yang disebut juga dengan teknik sampling jenuh. Teknik pengumpulan data menggunakan data primer dan sekunder dengan prosedur pengambilan data menggunakan observasi, wawancara serta kuesioner. Analisa data menggunakan analisa univariat dan analisa bivariat dengan menggunakan uji analisis chisquare. 


\section{HASIL DAN PEMBAHASAN Analisa Univariat}

Analisa univariat menggambarkan mengenai faktor individu pekerja seperti umur, indeks massa tubuh, kebiasaan merokok, masa kerja, posisi kerja dan nyeri punggung bawah (NPB).

Tabel 1

Distribusi Frekuensi Faktor Umur

\begin{tabular}{ccc}
\hline Umur & Frekuensi & $\begin{array}{c}\text { Persentase } \\
(\%)\end{array}$ \\
\hline $\begin{array}{c}<35 \\
\text { tahun }\end{array}$ & 37 & 43,5 \\
\hline $\begin{array}{c}\geq 35 \\
\text { tahun }\end{array}$ & 48 & 56,5 \\
\hline Total & 85 & 100 \\
\hline
\end{tabular}

Dari tabel diatas menunjukkan bahwa pada pekerja subcont bagian Indeks Massa Tubuh welding dari 85 responden memiliki karakteristik umur < 35 tahun sebanyak 38 orang $(44,7 \%)$ dan umur $\geq 35$ tahun sebanyak 47 orang $(55,3 \%)$.

Tabel 2

Distribusi Frekuensi Faktor IMT

\begin{tabular}{ccc}
\hline $\begin{array}{c}\text { Indeks } \\
\text { Masa } \\
\text { Tubuh }\end{array}$ & Frekuensi & $\begin{array}{c}\text { Persentase } \\
(\%)\end{array}$ \\
\hline $\begin{array}{c}\text { Kurus } \\
(<18,5)\end{array}$ & 17 & 20,0 \\
\hline $\begin{array}{c}\text { Normal } \\
(18,5-22,9)\end{array}$ & 33 & 38,8 \\
\hline $\begin{array}{c}\text { Overweight } \\
(\geq 23,0)\end{array}$ & 35 & 41,2 \\
\hline Total & $\mathbf{8 5}$ & $\mathbf{1 0 0}$ \\
\hline
\end{tabular}

Dari tabel diatas menunjukkan bahwa pada pekerja subcont yang bekerja pada bidang welding dari 85 responden memiliki karakteristik indeks massa tubuh kurus sebanyak 18 orang $(21,2 \%)$, indeks massa tubuh normal sebanyak 32 orang $(37,6 \%)$, dan pada indeks massa tubuh overweight sebanyak 35 orang $(41,2 \%)$.

Tabel 3

Distribusi Frekuensi Faktor Kebiasaan

\begin{tabular}{ccc}
\multicolumn{3}{c}{ Merokok } \\
\hline $\begin{array}{c}\text { Kebiasaan } \\
\text { Merokok }\end{array}$ & Frekuensi & $\begin{array}{c}\text { Persentase } \\
(\boldsymbol{\%})\end{array}$ \\
\hline Ya & 59 & 69,4 \\
\hline
\end{tabular}

\begin{tabular}{ccc}
\hline Tidak & 26 & 30,6 \\
\hline Total & $\mathbf{8 5}$ & $\mathbf{1 0 0}$ \\
\hline
\end{tabular}

Tabel diatas menunjukkan bahwa pekerja subcont pada bidang welding dari 85 orang responden memiliki karakteristik kebiasaan merokok sebanyak 59 orang $(69,4 \%)$ dan tidak memiliki kebiasaan merokok sebanyak 26 orang $(30,6 \%)$.

Tabel 4

Distribusi Frekuensi Masa Kerja

\begin{tabular}{ccc}
$\begin{array}{c}\text { Masa } \\
\text { Kerja }\end{array}$ & Frekuensi & $\begin{array}{c}\text { Persentase } \\
(\boldsymbol{\%})\end{array}$ \\
\hline$<5$ tahun & 31 & 36.5 \\
\hline$\geq 5$ tahun & 54 & 63.5 \\
\hline Total & $\mathbf{8 5}$ & $\mathbf{1 0 0}$
\end{tabular}

Dari tabel diatas menujukkan bahwa pekerja subcont pada bagian welding dari 85 responden didapati karakteristik masa kerja $<5$ tahun sebanyak 31 orang $(36,5 \%)$ dan karakterstik masa kerja $\geq 5$ tahun sebanyak 54 orang $(63,5 \%)$.

Tabel 5

Distribusi Frekuensi Posisi Kerja Posisi Kerja $\quad$ Frekuensi Persentase (\%)

\begin{tabular}{ccc}
\hline $\begin{array}{c}\text { Tidak janggal }(< \\
5)\end{array}$ & 29 & 34.1 \\
\hline Janggal $(\geq 5)$ & 56 & 65.9 \\
\hline Total & $\mathbf{8 5}$ & $\mathbf{1 0 0}$ \\
\hline
\end{tabular}

Dari tabel diatas menunjukkan bahwa pekerja subcont pada bagian welding dari 85 responden didapatkan karakteristik posisi kerja tidak janggal sebanyak 29 orang $(34,1 \%)$ dan karakteristik posisi kerja janggal sebanyak 56 orang $(65,9 \%)$.

Tabel 6

Distribusi Frekuensi Nyeri Punggung Bawah

\begin{tabular}{ccc}
\hline $\begin{array}{c}\text { Nyeri } \\
\text { Punggung } \\
\text { Bawah }\end{array}$ & Frekuensi & $\begin{array}{c}\text { Persentase } \\
(\boldsymbol{\%})\end{array}$ \\
\hline Ya & 48 & 56,5 \\
\hline Tidak & 37 & 43,5 \\
\hline Total & $\mathbf{8 5}$ & $\mathbf{1 0 0}$
\end{tabular}


Dari tabel diatas menunjukkan bahwa dari 85 responden didapati sebanyak 55 orang $(64,7 \%)$ merasakan nyeri punggung bawah dan sebanyak 30 orang $(35,3 \%)$ tidak merasakan nyeri punggung bawah.

Tabel 7

Distribusi Frekuensi Skala Nyeri Punggung Bawah

\begin{tabular}{ccc}
\hline $\begin{array}{c}\text { Skala Nyeri } \\
\text { Punggung Bawah }\end{array}$ & Frekuensi & $\begin{array}{c}\text { Persentase } \\
(\boldsymbol{\%})\end{array}$ \\
\hline Tidak Nyeri $(<4)$ & 35 & 41,2 \\
\hline Nyeri $(\geq 4)$ & 50 & 58,8 \\
\hline Total & $\mathbf{8 5}$ & $\mathbf{1 0 0}$ \\
\hline
\end{tabular}

Tabel diatas menunjukkan bahwa pekerja subcont bagian welding dari 85 orang responden didapatkan karakteristik tidak nyeri sebanyak 35 orang $(41,2 \%)$ dan karakteristik nyeri sebanyak 50 orang $(58,8 \%)$.

\section{Analisa Bivariat}

\section{Tabel 8}

Hubungan Umur Dengan Keluhan Nyeri Punggung Bawah

\begin{tabular}{|c|c|c|c|c|c|c|c|}
\hline \multirow{3}{*}{ Umur } & \multicolumn{4}{|c|}{ Nyeri Punggung Bawah } & \multicolumn{2}{|c|}{ Jumlah } & \multirow[t]{3}{*}{$\begin{array}{c}P \\
\text { value }\end{array}$} \\
\hline & \multicolumn{2}{|c|}{ Ya } & \multicolumn{2}{|c|}{ Tidak } & \multirow[b]{2}{*}{$\mathbf{N}$} & \multirow[b]{2}{*}{$\%$} & \\
\hline & n & $\%$ & $n$ & $\%$ & & & \\
\hline $\begin{array}{l}<35 \\
\text { tahun }\end{array}$ & 9 & 24,3 & 28 & 75,7 & 37 & 100 & \multirow{3}{*}{0,000} \\
\hline $\begin{array}{l}\geq 35 \\
\text { tahun }\end{array}$ & 39 & 81,3 & 9 & 18,8 & 48 & 100 & \\
\hline Total & 48 & 56,5 & 37 & 43,5 & 85 & 100 & \\
\hline
\end{tabular}

Berdasarkan tabel diatas menunjukkan hasil analisis hubungan umur dengan keluhan nyeri punggung bawah pada pekerja welding di PT X Kota Batam tahun 2020, diketahui sebanyak 85 responden pada usia $<35$ tahun didapakan 9 orang $(24,3 \%)$ mengalami nyeri punggung bawah dan $28 \quad(75,5 \%)$ tidak mengalami nyeri pungung bawah. Pada usia $\geq$ 35 tahun sebanyak 39 orang (81,3\%) mengalami nyeri punggung bawah dan sebanyak 9 orang $(18,8 \%)$ tidak mengalami nyeri punggung bawah.

Dari hasil uji statistik diperoleh $P$ value $=$ $0,000<\alpha=0,05$ dengan demikian maka Ha diterima, hal ini menunjukkan terdapat hubungan antara umur dengan keluhan nyeri punggung bawah pada pekerja welding di PT X Kota Batam tahun 2020.
Tabel 9

Hubungan IMT Dengan Keluhan Nyeri Punggung Bawah

\begin{tabular}{|c|c|c|c|c|c|c|c|}
\hline \multirow{3}{*}{ IMT } & \multicolumn{4}{|c|}{$\begin{array}{c}\text { Nyeri Punggung } \\
\text { Bawah }\end{array}$} & \multirow{2}{*}{\multicolumn{2}{|c|}{ Jumlah }} & \multirow{3}{*}{$\begin{array}{c}\mathrm{P} \\
\text { valu } \\
e\end{array}$} \\
\hline & \multicolumn{2}{|c|}{ Ya } & \multicolumn{2}{|c|}{ Tidak } & & & \\
\hline & $\mathbf{n}$ & $\%$ & n & $\%$ & $\mathbf{N}$ & $\%$ & \\
\hline Kurus & 5 & 29,4 & 12 & 70,6 & 17 & 100 & \\
\hline $\begin{array}{c}\text { Norm } \\
\text { al }\end{array}$ & 13 & 39,4 & 20 & 60,6 & 33 & 100 & 0,00 \\
\hline $\begin{array}{c}\text { Over } \\
\text { weigh } \\
t\end{array}$ & 30 & 85,7 & 5 & 14,3 & 35 & 100 & 0 \\
\hline Total & 48 & 56,5 & 37 & 43,5 & 85 & 100 & \\
\hline
\end{tabular}

Berdasarkan tabel diatas menunjukkan hasil analisis hubungan indeks massa tubuh dengan keluhan nyeri punggung bawah pada pekerja welding di PT X Kota Batam tahun 2020, diketahui dari 85 orang responden indeks massa tubuh kurus sebanyak 5 orang $(29,4 \%)$ mengalami nyeri punggung bawah dan sebanyak 12 orang $(70,6 \%)$ tidak mengalami nyeri punggung bawah. Normal sebanyak 13 orang $(39,4 \%)$ mengalami nyeri punggung bawah dan 20 orang $(60,6 \%)$ tidak mengalami nyeri punggung bawah. Dan overweight sebanyak 30 orang $(85,7 \%)$ mengalami nyeri punggung bawah dan 5 orang (14,3\%) tidak mengalami nyeri punggung bawah.

Dari hasil uji statistik diperoleh $p$ value $=$ $0,000<\alpha=0,05$ dengan demikian maka $\mathrm{Ha}$ diterima, hal ini menunjukkan terdapatnya hubungan antara indeks massa tubuh dengan keluhan nyeri punggung bawah pada pekerja welding di PT X Kota Batam tahun 2020.

Tabel 10

Hubungan Kebiasaan Merokok Dengan Keluhan Nyeri Punggung Bawah

\begin{tabular}{|c|c|c|c|c|c|c|c|}
\hline \multirow{3}{*}{$\begin{array}{c}\text { Kebia } \\
\text { saan } \\
\text { Mero } \\
\text { kok }\end{array}$} & \multicolumn{4}{|c|}{$\begin{array}{c}\text { Nyeri Punggung } \\
\text { Bawah }\end{array}$} & \multirow{2}{*}{\multicolumn{2}{|c|}{ Jumlah }} & \multirow[t]{3}{*}{$\begin{array}{c}\mathrm{P} \\
\text { value }\end{array}$} \\
\hline & \multicolumn{2}{|c|}{ Ya } & \multicolumn{2}{|c|}{ Tidak } & & & \\
\hline & $\mathbf{n}$ & $\%$ & $\mathbf{n}$ & $\%$ & $\mathbf{N}$ & $\%$ & \\
\hline $\mathrm{Ya}$ & 45 & 76,3 & 14 & 23,7 & 59 & $\begin{array}{c}10 \\
0\end{array}$ & \\
\hline Tidak & 3 & 11,5 & 23 & 88,5 & 26 & $\begin{array}{c}10 \\
0 \\
\end{array}$ & 0,000 \\
\hline Total & 48 & 56,5 & 37 & 43,5 & 85 & $\begin{array}{c}10 \\
0\end{array}$ & \\
\hline
\end{tabular}


Berdasarkan tabel diatas menunjukkan hasil analisian kebiasaan merokok dengan keluhan nyeri punggung bawah pada pekerja welding di PT X Kota Batam tahun 2020, diketahui bahwa dari 85 orang responden kebiasaan merokok sebanyak 45 orang $(76,3 \%)$ mengalami nyeri punggung bawah dan 14 orang $(23,7 \%)$ tidak mengalami nyeri punggung bawah. Pada responden tidak merokok sebanyak 3 orang $(11,5 \%)$ mengalami nyeri punggung bawah dan sebanyak 23 orang $(88,5 \%)$ tidak mengalami nyeri punggung bawah.

Dari hasil uji ststistik diperoleh $p$ value $=$ $0,000<\alpha=0,05$ dengan demikian maka Ha diterima, hal ini menunjukkan bahwa terdapat hubungan antara kebiasaan merokok dengan keluhan nyeri punggung bawah pada pekerja welding di PT X Kota Batam tahun 2020.

Tabel 11

Hubungan Masa Kerja Dengan Keluhan Nyeri Punggung Bawah

\begin{tabular}{cccccccc}
\hline & \multicolumn{4}{c}{$\begin{array}{c}\text { Nyeri Punggung } \\
\text { Bawah }\end{array}$} & Jumlah & $\begin{array}{c}\text { P } \\
\text { value }\end{array}$ \\
\cline { 2 - 5 } $\begin{array}{c}\text { Masa } \\
\text { Kerja }\end{array}$ & \multicolumn{2}{c}{ Ya } & \multicolumn{2}{c}{ Tidak } & & & \\
\cline { 2 - 6 } & $\mathbf{n}$ & $\%$ & $\mathbf{n}$ & $\%$ & $\mathbf{N}$ & $\%$ & \\
\hline $\begin{array}{c}<5 \\
\text { tahun }\end{array}$ & 6 & 19,4 & 25 & 80,6 & 31 & 100 & \\
\hline $\begin{array}{c}\geq 5 \\
\text { tahun }\end{array}$ & 42 & 77,8 & 12 & 22,2 & 54 & 100 & 0,000 \\
\hline Total & 48 & 56,5 & 37 & 43,5 & 85 & 100 & \\
\hline
\end{tabular}

Berdasarkan tabel diatas menunjukkan hasil analisis hubungan masa kerja dengan keluhan nyeri punggung bawah pada pekerja welding di PT X Kota Batam tahun 2020, diketahui bahwa dari 85 orang responden masa kerja $<5$ tahun sebanyak 6 orang $(19,4 \%)$ mengalami nyeri punggung bawah dan sebanyak 25 orang $(80,6 \%)$ tidak mengalami nyeri punggung bawah. Masa kerja $\geq 5$ tahun sebanyak 42 orang $(77,8 \%)$ mengalami nyeri punggung bawah dan 12 orang $(22,2 \%)$ tidak mengalami nyeri punggung bawah.

Dari hasil uji statistik diperoleh $p$ value $=$ $0,000<\alpha=0,05$ dengan demikian Ha diterima, hal ini menunjukkan bahwa terdapatnya hubungan antara masa kerja dengan keluhan nyeri punggung bawah pada pekerja welding di PT X Kota Batam tahun 2020.
Tabel 12

Hubungan Posisi Kerja Dengan Keluhan Nyeri Punggung Bawah

\begin{tabular}{|c|c|c|c|c|c|c|c|}
\hline \multirow{3}{*}{$\begin{array}{l}\text { Posisi } \\
\text { Kerja }\end{array}$} & \multicolumn{4}{|c|}{$\begin{array}{c}\text { Nyeri Punggung } \\
\text { Bawah }\end{array}$} & \multirow{2}{*}{\multicolumn{2}{|c|}{ Jumlah }} & \multirow[t]{3}{*}{$\begin{array}{c}\mathrm{P} \\
\text { value }\end{array}$} \\
\hline & \multicolumn{2}{|c|}{ Ya } & \multicolumn{2}{|c|}{ Tidak } & & & \\
\hline & $\mathbf{n}$ & $\%$ & $n$ & $\%$ & $\mathbf{N}$ & $\%$ & \\
\hline $\begin{array}{c}\text { Tidak } \\
\text { Janggal }\end{array}$ & 5 & 17,2 & 24 & 82,8 & 29 & 100 & \multirow{3}{*}{0,000} \\
\hline Janggal & 43 & 76,8 & 13 & 23,2 & 56 & 100 & \\
\hline Total & 48 & 56,5 & 37 & 43,5 & 85 & 100 & \\
\hline
\end{tabular}

Berdasarkan tabel diatas menunjukkan hasil analisis hubungan posisi kerja dengan keluhan nyeri punggung bawah pada pekerja welding di PT X Kota Batam tahun 2020, diketahui bahwa dari 85 orang responden posisi kerja tidak janggal sebanyak 5 orang $(17,2 \%)$ mengalami nyeri punggung bawah dan sebanyak 24 orang $(82,2 \%)$ tidak mengalami nyeri punggung bawah. Posisi kerja janggal sebanyak 43 orang $(76,8 \%)$ mengalami nyeri punggung bawah dan sebanyak 13 orang $(23,2 \%)$ tidak mengalami nyeri punggung bawah.

Dari hasil uji statistik diperoleh $p$ value $=$ $0,000<\alpha=0,05$ dengan demikian maka $\mathrm{Ha}$ diterima, hal ini menunjukkan adanya hubungan antara posisi kerja dengan keluhan nyeri punggung bawah pada pekerja welding di PT X Kota Batam tahun 2020.

\section{PEMBAHASAN}

\section{Hubungan Umur Dengan Keluhan Nyeri Punggung Bawah}

Umur ialah salah satu dari faktor yang dapat menyebabkan nyeri punggung bawah pada pekerja welding, hasil temuan dalam penelitian ini mengasumsikan bahwa pekerja dengan umur lebih tua berpeluang tinggi dalam mengalami nyeri punggung bawah dibandingkan dengan pekerja yang berumur masih muda.

Berdasarkan uji statistik, didapatkan pekerja yang memiliki umur tua $\geq 35$ tahun persentasenya lebih besar tingkat keluhan nyeri punggung bawah $(81,3 \%)$ dibandingkan dengan pekerja dengan umur muda $<35$ tahun $(24,3 \%)$. Melalui uji Chi-square didapatkan $P$ value sebesar 0,000 yang bermakna terdapat hubungan antara umur dengan keluhan nyeri punggung bawah pada pekerja welding. 
Dari hasil wawancara kepada pekerja dengan kuesioner, didapatkan hasil bahwa sebagian besar dari pekerja welding di PT X Kota Batam yang memiliki umur $\geq 35$ tahun mengatakan lebih mudah mengalami keluhan nyeri punggung bawah dan rasa nyeri pada punggung bawah biasanya di rasakan pada saat bekerja dan menganggu pekerjaan.

Variabel umur dalam penelitian ini memiliki hubungan yang bermakna dengan keluhan nyeri punggung bawah pada pekerja welding, dari hasil dilapangan didapatkan masih banyak pekerja yang berumur $\geq 35$ tahun maupun $<35$ tahun tidak melakukan olahraga seperti peregangan pada otot sebelum dan sesudah bekerja, hal inilah yang dapat memungkinkan terjadinya risiko pada nyeri punggung bawah.

Adapun beberapa hal yang mungkin dapat menyebabkan nyeri punggung bawah ialah pekerja telah melakukan pekerjaan sebelumnya sehingga pekerja sudah merasakan adanya rasa nyeri pada bagian punggung belakang yang terakumulasi dan dibawa di tempat kerja. Pekerja dengan umur $\geq 35$ tahun sebaiknya jangan membebani dengan pekerjaan yang bisa mengakibatkan otot pada punggung bawah merasa lelah dan mengalami keluhan nyeri punggung bawah pada saat pekerja memulai pekerjaannya. Peregangan dapat dilakukan sebelum dan sesudah melakukan kerja pada setiap harinya meskipun nyeri punggung bawah tidak dirasakan.

Hal ini sesuai dengan teori yang dikemukakan oleh (Tawarka, 2014), keluhan pertama dirasakan pada saat umur 35 tahun dan tingkat keluhan akan sering meningat dengan seiring bertambahnya usia. Kekuatan maksimal otot terjadi ketika umur antara 20 - 49 tahun, pada umur mencapai 60 tahun rata -rata kekuatan otot akan menurun sampai $20 \%$.

Hal ini juga sejalan dengan penelitian sebelumnya yang dilakukan (Annisa et al, 2016) oleh tentang faktor - faktor resiko yang berhubungan dengan kejadian nyeri punggung bawah pada pekerja konveksi industri di Mangkang dimana nilai $p=0,000(<0,05)$. Pada penelitian (Defriyan, 2011) menunjukkan adanya hubungan antara umur dengan keluhan nyeri punggung bawah pada proses penyulaman kain tapis di sanggar family art Bandar Lampung dengan nilai $\mathrm{p}=0,046(<0,05)$. Pada (Sasamu et al, 2017) penelitian tentang hubungan durasi mengemudi dan umur dengan keluhan nyeri punggung bawah pada pengemudi mikrolet jurusan Karombasan - pusat kota di Kota Manado dengan hasil nilai $\mathrm{p}$ $=0,023(<0,05)$. Dari (Wulandari \& Zaidah, 2019) penelitian tentang hubungan usia dan durasi lama duduk dengan keluhan nyeri punggung bawah pada pembatik di kampong batik Giriloyo dengan nilai $p=0,031(<0,05)$.

Hasil penelitian ini bertolak belakang dengan penelitian (Pratiwi et al, 2009) tentang beberapa faktor yang berpengaruh terhadap keluhan nyeri punggung bawah pada penjual jamu gendong dengan nilai $\mathrm{p}=0,355(>0,05)$. Pada penelitian (Patrianingrum et al, 2015) tentang Prevalensi dan Faktor Risiko Nyeri Punggung Bawah di Lingkungan Kerja Anestesiologi Rumah Sakit Dr. Hasan Sadikin Bandung menunjukkan tidak adanya hubungan antara umur dan keluhan nyeri punggung bawah pada lingkungan kerja anestesiologi Rumah Sakit Dr. Hasan Sadikin Bandung dengan nilai $\mathrm{p}=0,223(>0,05)$. Dari penelitian (Riningrum \& Widowati, 2016) mengenai pengaruh sikap kerja, usia, dan masa kerja terhadap keluhan low back pain terdapat hasil nilai $\mathrm{p}=0,554(>0,05)$. Pada penelitian (Wahab, 2019) tentang faktor faktor yang berhubungan dengan keluhan nyeri punggung bawah (low back pain) pada nelayan di Desa Batu Karas Kecamatan Cijulang Pangandaran dengan hasil $\mathrm{p}=0,214(>0,05)$. Dan pada penelitian (Noviyanti et al, 2020) tentang faktor risiko ergonomi terhadap keluhan nyeri otot pada pekerja batu bata dengan hasil $\mathrm{p}$ $=0,165(>0,05)$.

Menurut asumsi peneliti nyeri punggung yang dirasakan pada pekerja welding di PT X ini lebih bnayak dialami oleh pekerja yang memiliki umur $\geq 35$ tahun, dikarnakan pada umur segini pekerja rentan untuk mengalami gangguan pada kesehatan dan juga pada pekerja umur $\geq 35$ tahun masih banyak yang tidak melakukan peregangan otot sehingga dengan mudah terkena nyari punggung bawah. Nyeri punggung bawah ini juga sering terjadi pada usia $\geq 35$ tahun dikarenakan menurunnya kekuatan otot pada tulang belakang sehingga dengan mudah mengalami nyeri pada punggung bagian belakang.

\section{Hubungan Indeks Massa Tubuh Dengan Keluhan Nyeri Punggung Bawah}

Indeks massa tubuh atau yang disebut juga dengan antropometri ialah pengukuran yang digunakan secara sistematis terhadap tubuh manusia. Dalam penelitian ini indeks massa tubuh di kategorikan menjadi 3 kategori yaitu 
kurus > 18,5, normal 18,5 - 22,9, dan overweight $\geq 23,0$.

Dari hasil statistik pada tabel 4.9 didapatkan pekerja yang memiliki kategori IMT overweight persentasenya lebih besar tingkat keluhan nyeri punggung bawah $(85,7 \%)$ dibandingkan dengan pekerja yang memiliki kategori IMT kurus $(29,4 \%)$ dan normal $(39,4 \%)$. Melalui uji Chi-square didapatkan $P$ value sebesar 0,000 yang artinya terdapat hubungan antara indeks massa tubuh dengan keluhan nyeri punggung bawah pada pekerja welding di PT X Kota Batam.

Dari hasil ukur IMT dengan menggunakan alat ukur berat badan dan tinggi badan yang berpedoman pada lembar bathroomscale dan Microtoise, didapatkan hasil bahwa sebagian besar pekerja welding di PT X Kota Batam yang memiliki IMT overweight lebih memungkinkan untuk terjadinya nyeri punggung bawah.

Variabel indeks massa tubuh pada penelitian ini memiliki hubungan yang bermakna pada keluhan nyeri punggung bawah pada pekerja welding, didapatkan dari hasil lapangan pada para pekerja yang memiliki indeks massa tubuh overweight dan kurus kurang untuk menjaga pola makan. Dimana pada para pekerja yang memiliki indeks massa tubuh overweight mereka lebih banyak mengkomsumsi makanan yang banyak mengandung lemak jahat sehingga dapat mengalami kegemukan pada tubuh. Dan rata rata pekerja yang memiliki indeks massa tubuh overweight yaitu pekerja yang berumur $\geq 35$ tahun.

Pada pekerja yang mengalami overweight ini sama malas untuk melakukan peregangan saat melakukan pekerja terlebih dahulu dikarenakan badan yang yang gemuk dan susah untuk bergerak inilah yang membuat pekerja enggan untuk melakukan peregangan. Bukan hanya pada pekerja yang memiliki indeks massa tubuh overweight saja tetapi pada pekerja yang memiliki indeks massa tubuh kurus dan normal.

Pada pekerja yang memiliki indeks massa tubuh kurus dilihat dari observasi lapangan pada pagi hari mereka tidak membiasakan diri untuk sarapan di pagi hari lebih mengutamakan merokok sebelum bekerja dibandingkan sarapan sebelum bekerja.

Ketika berat badan semakin meningkat maka tulang belakang akan tertekan dalam menerima beban sehingga memudahkan untuk kerusakan serta bahaya pada struktur tulang tersebut. Bila hal ini terjadi secara terus menurus maka mengakibatkan penekanan pada bantalan syaraf pada tulang belakang dan menyebabkan hernia nucleus pulposus (Annisa et al, 2016).

Hal ini sejalan dengan teori, Keluhan sistem musculoskeletal yang berkaitan dengan ukuran tubuh lebih disebabkan oleh keseimbangan struktur rangka dalam menerima beban, baik beban berat tubuh maupaun beban tambahan lainnya (Tawarka, 2010). Kondisi IMT yang tinggi akan mengakibatkan beban beban tubuh semakin bertambah karena adanya penimbunan pada lemak di perut yang menyebabkan penekanan pada tulang belakang dan mengakibatkan tulang belakang tidak stabil (Wulandari \& Zaidah, 2019).

Hal ini juga sejalan dengan penelitian (Annisa et al, 2016) tentang faktor - faktor risiko yang berhubungan dengan kejadian nyeri punggung bawah pada pekerja konveksi industri di Mangkang dengan hasil uji chisquare dengan kolmogorov-smirnov didapatkan nilai $\mathrm{p}=0,001 \quad(<0,05)$. Penelitian (Purnamasari, 2010) mengenai overweight sebagai faktor resiko low back pain pada pasien poli saraf RSUD Prof. Dr. Margono Soekarjo Purwokerto didapatkan adanya hubungan overweight dengan nyeri punggung bawah dengan hasil nilai $\mathrm{p}=0,032(<0,05)$. Pada (Legiran, 2014) penelitian tentang nyeri pinggang dan faktor -faktor risiko yang mempengaruhinya didapatkan hasil uji chisquare dengan nilai $\mathrm{p}=0,04(<0,05)$ yang berarti adanya hubungan antara indeks massa tubuh dengan kejadian nyeri punggung bawah. Dari hasil penelitian (Jeremy, 2019) tentang faktor - faktor yang berhubungan dengan keluhan NPB pada pengemudi di CV. Bandar Jaya Pematangsiantar menunjukkan ada hubungan antara indeks massa tubuh dengan keluhan NPB dengan hasil nilai $\mathrm{p}=0,042(<$ $0,05)$.

Hasil penelitian ini bertolak belakang dengan penelitian (Patrianingrum et al, 2015) tentang pravalensi dan faktor resiko nyeri punggung bawah di lingkungan kerja anestesiologi Rumah Sakit Dr. Hasan Sadikin Bandung dengan nilai $\mathrm{p}=0,154$ (> 0,05). Penelitian (Sitepu, 2015) mengenai faktor faktor yang berhubungan dengan keluhan low back pain pada petani jeruk di Desa Dokan Kecamtan Merek Kabupaten Karo Tahun 2015 dengan hasil nilai $\mathrm{p}=0,178(>0,05)$. Dari (Wahab, 2019) penelitian mengenai faktor - 
faktor yang berhubungan dengan keluhan nyeri punggung bawah (low back pain) pada nelayan di Desa Batu Karas Kecamatan Cijulang Pengandaran didapatkan hasil nilai $\mathrm{p}=0,199$ (> $0,05)$ yang bermakna tidak ada hubungan antara indeks massa tubuh dengan keluhan nyeri punggung pada nelayan di Desa Batu Karas Kecamatan Cijulang Pengandaran. Dan juga pada penelitian (Sinaga \& Salmah, 2015) tentang hubungan faktor resiko dengan terjadinya nyeri punggung bawah (low back pain) pada tenaga kerja bongkat muat di pelabuhan belawan Medan tahun 2015 dengan hasil nilai $\mathrm{p}=0,613(>0,05)$. Dan pada penelitian (Noviyanti et al, 2020) tentang faktor risiko ergonomic terhadap keluhan nyeri otot pada pekerja pembuat batu bata dengan hasil $\mathrm{p}$ $=0,343(>0,05)$.

Menurut asumsi peneliti banyaknya pekerja welding di PT X yang mengalami nyeri punggung bawah rata-rata terjadi pada pekerja yang memiliki indeks massa tubuh overweight dikarenakan bentuk tubuh yang gemuk membuat pekerja malasnya untuk melakukan peregangan pada tubuh sebelum bekerja sehingga menyebabkan timbulnya rasa nyeri pada nagian tubuh dan juga dikarenakan berlebihannya kadar gizi didalam tubuh menyebabkan ukuran otot mengecil sehingga mengurangi segi metabolisme untuk meningkatkan energi. Jika energi dalam tubuh dihasilkan sangat rendah maka terjadinya kelelahan otot dan akan terjadi risiko nyeri punggung bawah.

\section{Hubungan Kebiasaan Merokok Dengan Keluhan Nyeri Punggung Bawah}

Kebiasaan merokok ialah aktivitas seseorang yang merespons orang tersebut terhadap rangsangan dari luar ialah faktor faktir yang dapat mempenagruhi seseorang untuk merokok dan bisa diamati secara langsung (Santoso, 2015).

Dari hasil statistik pada tabel 4.10 didapatkan bahwa pekerja yang memiliki kebiasaan merokok (76,3\%) lebih besar persentasenya dibangdingkan dengan pekerja yang tidak memiliki kebiasaan merokok (11,5\%). Melalui uji Chi-square didapati $P$ value sebesar 0,000 yang berarti terdapat hubungan yang signifikan antara kebiasaan merokok dengan keluhan nyeri punggung bawah pada pekerja welding di PT X Kota Batam.
Dari hasil wawancara dengan menggunkaan kuesioner dan pemantauan dilapangan, didapatkan hasil bahwa sebagian besar pekerja memiliki kebiasaan merokok dan rata - rata pekerja merokok pada saat bekerja. Semakin lama serta tingginya frekuensi merokok, maka semakin tinggi pula tingkatan pada keluhan nyeri punggung bawah yang dirasakan. Karena nikotin yang tekandung dalam rokok dapat menyebabkan berkurangnya aliran darah kejaringan serta berkurangnya mineral pada tulang sehingga menyebabkan nyeri dibagian tulang belakang.

Dari hasil penelitian dilapangan sebanyak 42 orang menghabiskan rokok dalam sehari $\geq 10$ batang dan telah mengkomsumsi rokok selama $\geq 10$ tahun. Variabel kebiasaan merokok pada penelitian ini memiliki hubungan yang bermakna pada keluhan nyeri punggung bawah pada pekerja welding di PT X. Tidak adanya larangan untuk merokok dari perusahaan tersebut sehingga pekerja terus mengkomsumsi rokok dalam waktu bekerja dan tidak bekerja. Para pekerja banyak mengetahui akan bahayanya merokok tetapi tetap saja mereka komsumsi. Ada juga pekerja yang tidak merokok tetapi mengalami nyeri pada punggung bawah biasanya diakibatkan karena faktor usia dan juga pada posisi saat bekerja.

Hal ini sejalan dengan teori yang menyatakan hubungan antara kebiasaan merokok dengan keluhan otot pingang sangatlah signifikan terkhusus untuk pekerjaan yang memerlukan pengerahan otot. Kebiasaan merokok akan menurunkan kapasitas paru paru, sehingga kemampuan mengkomsumsi oksigen menurun dan akibatnya tingkat kesegaran tubuh juga menurun. Dengan melakukan pekerjaan yang menuntut pengerhan tenaga maka akan mudah lelah karena kandungan oksigen dalam darah renda, pembakaran karbohidrat terhambat, sehingga terjadinya penumpukan asam laktat dan menimbulkan rasa nyeri pada otot (Benynda, 2016).

Hal ini sejalan dengan penelitian (Patrianingrum et al, 2015) tentang pravalensi dan faktor risiko nyeri punggung bawah di lingkungan kerja anestesiologi Rumah Sakit Dr. Hasan Sadikin Bandung dengan hasil nilai $\mathrm{p}=$ 0,011 (< 0,05). Penelitian (Wahab, 2019) mengenai faktor - faktor yang berhubungan dengan keluhan nyeri punggung bawah (low back pain) pada nelayan di Desa Batu Karas Kecamatan Cijulang Pangandaran didapatkan 
hasil nilai $\mathrm{p}=0,021(<0,05)$ yang bermakna adanya hubungan antara kebiasan merokok dengan keluhan nyeri punggung pada nelayan di Desa Batu Karas Kecamatan Cijulang Pangandaran. Pada penelitian (Sitepu, 2015) tentang faktor -faktor yang berhubungan dengan keluhan low back pain pada petani jeruk di Desa Dokan Kecamatan Merek Kabupaten Karo tahun 2015 dengan nilai $\mathrm{p}=0,032$ (< 0,05). Dan pada penelitian (Legiran, 2014) tentang nyeri pinggang dan faktor - faktor risiko yang mempengaruhinya dengan hasil dari uji chi-square didapatkan nilai $\mathrm{p}=0,04(<0,05)$ yang berarti adanya hubungan antara merokok dengan nyeri punggung bawah.

Hal ini bertolak belakang dengan penelitian (Septiawan, 2014) tentang faktor faktor yang berhubungan dengan keluhan nyeri punggung bawah pada pekerja bagunan di PT. Mikroland Property Devolopment Semarang tahun 2012 dengan hasil nilai $p=0,548(>0,05)$ bermakna tidak ada hubungan antara kebiasaan merokok dengan keluhan nyeri punggung bawah pada pekerja bangunan di PT. Mikroland Property Devolopment Semarang tahun 2012. Pada penelitian (Jeremy, 2019) mengenai faktor - faktor yang berhubungan dengan keluhan nyeri punggung bawah (low back pain) pada pengemudi angkutan kota CV. Bandar Jaya Pemantangsiantar dengan hasil $\mathrm{p}=0,681$ (> 0,05). Penelitian (Sinaga \& Salmah, 2015) tentang hubungan faktor resiko dengan terjadinya nyeri punggung bawah (low back pain) pada tenaga kerja bongkar muat (TKBM) di pelabuhan belawan Medan tahun 2015 diapatkan hasil nilai $\mathrm{p}=1,000(>0,05)$ maka penelitian ini bermakna tidak adanya hubungan antara merokok dengan kejadian nyeri punggung bawah pada tenaga kerja bongkar muat di pelabuhan belawan Medan tahun 2015. Dan pada penelitian (Defriyan, 2011) tentang faktor - faktor yang berhubungan dengan keluhan nyeri punggung bawah pada proses penyulaman kain tapis di sanggar family art Bandar Lampung tahun 2011 memiliki nilai $\mathrm{p}=$ $1,000(>0,05)$.

Menurut asumsi peneliti pekerja yang memiliki kebiasaan merokok akan lebih mudah untuk mengalami nyeri punggung bawah, karena dari sebagian pekerja yang merokok tidak menyadari ataupun tidak mengetahui bahwa rokoklah salah satu dari faktor resiko penyebab terjadinya nyeri punggung bawah. Kebiasaan merokok dikarenakan kandungan nikotin dalam rokok menyebabkan terhambatnya masuk oksigen serta mineral kedalam jaringan sehingga menyebabkan nyeri pada tulang bagian belakang.

\section{Hubungan Masa Kerja Dengan Keluhan Nyeri Punggung Bawah}

Masa kerja ialah panjangnya waktu yang terhitung dari pertama kali pekerja masuk kerja hingga saat penelitian dilakukan. Dalam oenelitian ini masa kerja dibagi 2 (dua) yaitu masa kerja $<5$ tahun dan masa kerja $\geq 5$ tahun.

Dari hasil uji statistik pada tabel 4.11 pekerja yang masa kerjanya $\geq 5$ tahun lebih banyak persentasenya mengalami keluhan nyeri punggung bawah $(77,8 \%)$ dibandingkan dengan pekerja dengan masa kerja $<5$ tahun $(19,4 \%)$. Melalui uji Chi-square didapatkan $P$ value sebesar 0,000 yang berarti terdapat hubungan antara masa kerja dengan keluhan nyeri punggung bawah pada pekerja welding di PT X Kota Batam.

Dari hasil wawancara dengan menggunakan kuesioner dan pemantauan dilapangan didapatkan hasil bahwa sebagaian besar pekerja di PT X Kota Batam yang memiliki masa kerja $\geq 5$ tahun lebih memungkinkan untuk mengalami nyeri punggung bawah dibandingkan dengan pekerja dengan masa kerja $<5$ tahun. lamanya pekerja bekerja pada suatu industri, dapat mempengaruhi kesakitan musculoskeletal yang dirasakan.

Variabel masa kerja memiliki hubungan yang bermakna dengan keluhan nyeri punggung bawah karna rata - rata pekerja yang memiliki masa kerja $\geq 5$ tahun memiliki usia $\geq 35$ tahun. Dan para pekerja tidak menyadari akan faktor resiko yang menyebabkan nyeri punggung bawah sering terpapar sehingga mereka tidak melakukan pengendalian untuk menghilangkan faktor resiko tersebut. Pada masa kerja $<5$ tahun juga ada yang yang mengalami nyeri punggung bawah yang dikarenakan kebiasaan kebiasaan kerja yang buruk seperti posisi kerja yang tidak baik, mengkomsumsi rokok dalam jumlah yang banyak perharinya serta faktor faktor lain yang menyebabkan terjadinya keluhan nyeri punggung bawah.

Hal ini sejalan dengan teori OSHA yaitu semakin lama masa kerja maka semakin lama juga seseorang melakukan pekerjaannya dengan posisi yang salah dan berulang sehingga mengakibatkan meningkatnya risiko terjasinya nyeri punggung bawah. Pengulangan gerakan dengan secara terus menerus hingga waktu 
bertahun - tahun menyebabkan kekuatan pada sendi- sendi di tubuh menjadi menurun serta akan berisiko timbulnya nyeri dan akan berpengaruh pada timbulnya kelelahan musculoskeletal yang dapat mengakibatkan menurunnya produktivitas (OSHA, 2014).

Hal ini sejalan dengan penelitian (Annisa et al, 2016) tentang faktor - faktor risiko yang berhubungan dengan kejadian nyeri punggung bawah pada pekerja konveksi industri di Mangkang dengan hasil nilai $\mathrm{p}=0,000(<0,05)$. Penelitian (Rochmawan \& Hariyono, 2017) tentang masa kerja, sikap kerja, dan keluhan low back pain (LBP) pada pekerja bagian produksi PT. Surya Besindo Sakti Serang dengan nilai $p$ $=0,005(<0,05)$ yang berari adanya hubungan antara masa kerja dengan keluhan nyeri punggung bawah pada pekerja bagian produksi PT. Surya Besindo Sakti Serang. Pada penelitian (Jeremy, 2019) mengenai faktor faktor yang berhubungan dengan keluhan nyeri punggung bawah (low back pain) pada pengemudi angkutan kota CV. Dan pada penelitian (Riningrum \& Widowati, 2016) tentang pengaruh sikap kerja, usia, dan masa kerja terhadap terjadinya keluhan low back pain dengan hasil nilai $\mathrm{p}=0,040(<0,05)$.

Hal ini bertolak belakang dengan penelitian (Zaman, 2014) tentang hubungan beberapa faktor dengan keluhan nyeri punggung bawah pada karyawan kantor dengan hasil nilai $\mathrm{p}=0,608(>0,05)$ yang bermakna tidak ada hubungan yang signifikan antara masa kerja dengan keluhan nyeri punggung bawah pada karyawan kantor. Dan pada (Pratiwi et al, 2009) penelitian tentang beberapa faktor yang berpengaruh terhadap keluhan nyeri punggung bawah pada penjual jamu gendong dengan hasil nilai $\mathrm{p}=1,000(>0,05)$ yang artinya tidak ada hubungan antara masa kerja dengan keluhan nyeri punggung pada penjual jamu gendong.

Menurut asumsi peneliti dari kejadian dilapangan banyaknya pekerja yang merasakan dan mengalami nyeri punggung bawah pada pekerja yang masa kerja $\geq 5$ tahun. Karna pada pekerja bagian welding yang bekerja $\geq 5$ tahun ini sudah sangat sering terpapar oleh faktorfaktor resiko terjadinya nyeri punggung maka para para pekerja yang masa kerjanya $\geq 5$ tahun lebih banyak mengalami nyeri punggung bawah. Karena tidak mengetahui atau tidak menyadari adanya faktor resiko tersebut sehingga tidak ada pengendalian yang dilakukannya seperti peregangan pada otot.

\section{Hubungan Posisi Kerja Dengan Keluhan Nyeri Punggung Bawah}

Posisi kerja dalam posisi menjongkok dan membungkuk dengan waktu yang terlalu lama dapat menyebabkan otot - otot menjadi spasme dan akan merusak jaringan lunak. Pada penelitian ini posisi kerja dibagi menjadi 2 (dua) kategori yaitu posisi janggal dan posisi tidak janggal.

Pada penelitian ini posisi kerja pada pekerja welding bukan hanya posisi kerja duduk maupun jongkok tetapi juga ada welding yang bekerja dengan posisi berdiri. Welding yang bekerja pada posisi berdiri ini melakukan pekerjaan menyambung bagian-bagian dari kapal yang berada di ketinggian sehingga posisi kerja welding ini bediri dengan kepala mendongak ke atas dan posisi kaki yang tegak.

Dari hasil uji statistik pada tabel 4.12 pekerja yang posisi kerjanya janggal lebih besar persentasenya mengalami keluhan nyeri punggung bawah $(76,8 \%)$ dibandingkan dengan pekerja yang posisi kerjanya tidak janggal (17,2\%). Hasil uji Chi-square didapatkan $P$ value sebesar 0,000 yang bermakna terdapat hubungan antara posisi kerja dengan keluhan nyeri punggung bawah pada pekerja welding di PT X Kota Batam.

Dari hasil ukur posisi tubuh menggunakan kuesioner yang berpedoman pada lembar observasi RULA dan pengamatan dilapangan, didapatkan hasil semakin tinggi nilai pada observasi RULA maka semakin tinggi keluhan nyeri punggung bawah dibandingkan dengan nilai pada observasi RULA rendah. Sikap kerja mempunyai hubungan dengan keluhan nyeri punggung karena posisi kerja yang salah, canggung, dan diluar kebiasaan akan menambah risiko cidera pada bagian sistem musculoskeletal.

Variabel posisi kerja pada penelitian ini memiliki hubungan yang bermakna dengan keluhan nyeri punggung bawah pada pekerja welding di PT X Kota Batam. Posisi tubuh yang diamati dilapangan banyak pekerja dan rata rata pada pekerja welding memiliki posisi kerja yang tidak baik ataupun janggal. Ada pun posisi kerja yang tidak janggal pada pekerja welding yaitu saat mengelas pada bagian tinggi yang mengharuskan pekerja berada posisi berdiri tegak dengan kepala sedikit mendongak ataupun kepala lurus menghadap dengan barang yang akan dilas. 
Hal ini sejalan dengan teori yang dikemukakan oleh (Tawarka, 2017) posisi kerja yang tidak ergonimis maka dapat menyebabkan kelelahan dan cedera pada otot. Posisi kerja yang tidak alamiah ialah posisi kerja yang menyebabkan posisi bagian tubuh bergerak menjauhi posisi tubuh alamiah. Misalkan pada saat melakukan pergerakan tangan terangkat, maka semakin jauh bagian tubuh dari pusat gravitasi maka semakin tinggi risiko akan terjadinya keluhan otot skeletal.

Hal ini sejalan dengan penelitian (Annisa et al, 2016) tentang faktor - faktor yang berhubungan dengan kejadian nyeri punggung bawah pada pekerja konveksi industri di Mangkang dengan nilai $p=0,002(<0,05)$. Pada penelitian (Nauli, 2015) tentang hubungan posisi kerja pasa pekerja industri batu bata dengan kejadian low back pain dengan hasil nilai $\mathrm{p}=0,002(<0,05)$ yang bermakna adanya hubungan signifikan antara posisi kerja dengan kejadian nyeri punggung bawah pada pekerja industri batu bara. Penelitian (Maizura, 2015) mengenai faktor - faktor yang berhubungan dengan keluhan nyeri punggung bawah (NPB) pada pekerja di PT. Bakrie Metal Industries tahun 2015 dengan hasil nilai $p=0,002(<0,05)$. Dan penelitian (Sumekar \& Natalia, 2010) mengenai nyeri punggung pada operator komputer akibat posisi dan lama duduk didapatkan hasil nilai $\mathrm{p}=0,011(<0,05)$ yang bermakna adanya hubungan antara posisi kerja dengann keluhan nyeri punggung bawah pada operator komputer.

Hal ini bertolak belakang dengan penelitian (Patrianingrum et al, 2015) tentang pravalensi dan faktor resiko nyeri punggung bawah di lingkungan kerja anestesiologi Rumah Sakit Dr. Hasan Sadikin Bandung dengan nilai $\mathrm{p}=0,25(>0,05)$. Penelitian (Fatoni \& Swasti, 2012) tentang hubungan sikap dan posisi kerja dengan low back pain pada perawat RSUD Purbalingga dengan hasil nilai $\mathrm{p}=0,272$ (> $0,05)$ maka bermakna tidak ada hubungan signifikan antara posisi kerja dengan nyeri punggung bawah pada perawat RSUD Purbalingga. Pada penelitian (Situpang, 2019) tentang hubungan posisi, durasi, dan masa bekerja dengan kejadian nyeri punggung bawah (NPB) pada masyarakat penenun ulos di Desa Lumban Suhi - Suhi Kecamatan Pangururan Kabupaten Samosir Sumatera Utara dengan hasil nilai $\mathrm{p}=0,367(>0,05)$. Dan pada penelitian (Defriyan, 2011) mengenai faktor faktor yang berhubungan dengan keluhan nyeri punggung bawah pada proses penyulaman kain tapis di sanggar family art Bandar Lampung tahun 2011 dengan hasil $p=0,602(>0,05)$ yang bermakna tidak ada hubungan antara posisi kerja dengan keluhan nyeri punggung bawah pada pekerja penyulaman kain tapis di sanggar family art Bandar Lampung.

Menurut asumsi peneliti pada kejadian dilapangan terdapat nyeri punggung bawah banyak terjadi pada pekerja yang memiliki posisi kerja janggal. Posisi kerja yang janggal ini diakibatkan karna kurang pemahaman dari pekerja cara ataupun bekerja dengan posisi kerja yang baik serta nyaman. Sehingga masih banyak pekerja yang bekerja dengan posisi janggal yang mengakibatkan timbulnya rasa nyeri pada punggung bagian bawah.

\section{SIMPULAN DAN SARAN}

Adanya hubungan Faktor individu (usia, IMT, kebiasaan merokok dan masa kerja) dengan keluhan nyeri punggung bawah ( $p$ value $=$ 0,000), dan hubungan Faktor pekerjaan (posisi kerja) dengan keluhan nyeri punggung bawah ( $p$ value $=0,000)$.

Perusahaan agar dapat memberikan penyuluhan mengenai faktor - faktor resiko yang dapat menyebabkan terjadinya keluhan nyeri punggung bawah dan melakukan pelatihan mengenai risiko pekerjaan dan tata cara bekerja yang sesuai dengan prinsip ergonomic serta membuat SOP yang bisa digunakan oleh pekerja untuk menciptakan sistem kerja yang sehat, aman dan nyaman. Untuk karyawan disarankan melakukan peregangan otot pada saat sebelum dan sesudah bekerja, istirahat apabila sudah merasakan nyeri pada daerah punggung bawah, dan perhatikan posisi tubuh saat bekerja segera perbaiki bila posisi tubuh menyebabkan rasa nyeri.

\section{DAFTAR PUSTAKA}

Annisa Titiani Purjayanti, Dwi Retnaningsih, A. (2016). Faktor - Faktor Resiko yang Berhubungan dengan Kejadian Nyeri Punggung Bawah pada Pekerja Konveksi Industri di Mangkang. 1-11.

Benynda, T. (2016). Hubungan Cara Kerja Angkat Angkut Dengan Keluhan Low Back Pain Pada Porter Di Pasar Tanah Abang Blok A Jakarta Pusat Tahun 2016. Jurnal Kesehatan Masyarakat, 1-37. Retrieved from chromeextension://oemmndcbldboiebfnladdacbd fmadadm/https://digilib.esaunggul.ac.id/p 
ublic/UEU-Undergraduate-7149-

ABSTRAK.pdf

Fatoni, H., \& Swasti, K. G. (2012). Hubungan Sikap Dan Posisi Kerja Dengan Low Back Pain Pada Perawat RSUD Purbalingga. Soedirman Journal of Nursing, 7(2), 8692.

Fiqih Naila Fikar, Suroto, B. W. (2017). HUBUNGAN INDEKS MASSA TUBUH, DURASI KERJA, DAN BEBAN KERJA FISIK TERHADAP KEBUGARAN JASMANI KARYAWAN KONSTRUKSI DI PT. X. Jurnal Kesehatan Masyarakat, 5(9), 359368.

https://doi.org/10.1017/CBO9781107415 324.004

Hendy Purnamasari, U. G. \& L. R. (2010). Overweight Sebagai Faktor Resiko Low Back Pain Pada Pasien POLI SARAF RSUD PROF. DR. MARGONO SOEKARJO PURWOKERTO. Mandala of Health, 4(January 2010), 26-32.

Huryah, F., \& Susanti, N. (2019). Pengaruh Terapi Pijat Stimulus Kutaneus SlowStroke Back Massage Terhadap Intensitas Nyeri Pada Penderita Low Back Pain (Lbp) Di Poliklinik Rehabilitasi Medik Rsud Embung Fatimah Batam Tahun 2018. 8, 1-7.

I Gusti Putu Ngurah Adi Santika, S.Pd., M. F. (2015). Hubungan Indeks Massa Tubuh (Imt) Dan Umur Terhadap Daya Tahan Umum (Kardiovaskuler) Mahasiswa Putra Semester Ii Kelas A Fakultas Pendidikan Olahraga Dan Kesehatan Ikip Pgri Bali Tahun 2014. Jurnal Pendidikan Kesehatan Rekreasi, 1(4), 53.

Karima, N., Idayanti, I., \& Umar, F. (2018). Pengaruh Masa Kerja, Pelatihan Dan Motivasi Terhadap Produktivitas Kerja Karyawan Pada Pt. Bank Sulselbar Cabang Utama Makassar. Hasanuddin Journal of Applied Business and Entrepreneurship, 1(1), 49-64.

Koesyanto, H. (2013). Masa Kerja Dan Sikap Kerja Duduk Terhadap Nyeri Punggung. KESMAS - Jurnal Kesehatan Masyarakat, 9(1), 9-14. https://doi.org/10.15294/kemas.v9i1.2824

Lukman dan Nurna Ningsih. (2012). Asuhan Keperawatan Pada Klien dengan Gangguan Sistem Musculoskeletal. Jakarta: Salemba Medika.

Maizura, F. (2015). Faktor-Faktor Yang
Berhubungan Dengan Keluhan Nyeri Punggung Bawah (NPB) Pada Pekerja Di Pt. Bakrie Metal Industries Tahun 2015. In Biomass Chem Eng (Vol. 49). Retrieved from

http://repository.uinjkt.ac.id/dspace/bitstr eam/123456789/29632/1/FEBRIANA MAIZURA-FKIK.pdf

Munir, S. (2012). Analisis Nyeri Punggung Bawah Pada Pekerja Bagian Final Packing Dan Part Supply Di PT. X Tahun 2012. Tesis.

Noviyanti, Dwi Cahyani Misriningsih, D. M. (2020). FAKTOR RISIKO ERGONOMI TERHADAP KELUHAN NYERI OTOT PADA PEKERJA PEMBUAT BATU BATA. 2(1), 1-11. https://doi.org/10.3652/J-KIS

Pratiwi, M., Setyaningsih, Y., \& Kurniawan, B. (2009). Beberapa Faktor Yang Berpengaruh Terhadap Keluhan Nyeri Punggung Bawah Pada Penjual Jamu Gendong. $\quad 4(1)$, 61-67. https://doi.org/10.14710/jpki.4.1.61-67

Putra, et al. (2012). Hubungan Usia, Lama Kerja, dan Kebiasaan Merokok dengan Fungsi Paru pada Juru Parkir di Jalan Pandanaran Semarang. Jurnal Kedokteran Muhammadiyah, 1(3), 8-9.

Ramacahya, M., Mury, K., \& Dudung, A. (2017). Asupan Energi dan Zat Gizi Makro, Kebiasaan Merokok, Konsumsi Alkohol dan Kuantitas Tidur Terhadap kebugaran dan Keterampilan Shooting atlet Basket ASPAC Jakarta. Jurnal.

Rochmawan, E. A., \& Hariyono, W. (2017). Masa Kerja, Sikap Kerja, dan Keluhan Low Back Pain (LBP) Pada Pekerja Bagian Produksi PT Surya Besindo Sakti Serang. Seminar Nasional IKAKESMADA "Peran Tenaga Kesehatan Dalam Pelaksaan SDGs,” (1), 171-180. Retrieved from http://eprints.uad.ac.id/5393/

Septiawan, H. (2014). Faktor Berhubungan Keluhan Nyeri Punggung Bawah Pada Pekerja Bangunan Pt Mikroland Semarang. Unnes Journal of Public Health, 2(2).

Sumekar, D. W., \& Natalia, D. (2010). Nyeri Punggung pada Operator Komputer Akibat Posisi dan Lama Duduk. Majalah Kedokteran Bandung, 42(3), 123-127. https://doi.org/10.15395/mkb.v42n3.23

Tawarka. (2010). Ergonomi Industri: Dasar- 
dasar Pengetahuan Ergonomi dan Aplikasi di Tempat Kerja. Surakata: Harapan Press Solo.

Tawarka. (2014). Ergonomi Industri. Surakarta: Harapan Press.

Tawarka. (2017). Ergonomi Industri DasarDasar Pengetahuan Ergonomi Dan Aplikasi di Tempat Kerja. Surakarta: Harapan Press.

Wahab, A. (2019). Faktor-Faktor Yang Berhubungan Dengan Keluhan Nyeri Punggung Bawah (Low Back Pain) Pada Nelayan Di Desa Batu Karas Kecamatan Cijulang Pangandaran. Biomedika, 11(1), 35.

https://doi.org/10.23917/biomedika.v11i1 .7599

Wardhani, U. C. (2018). Hubungan Mekanika Tubuh Dengan Kejadian Lowback Pain Pada Perawat Ruang Icu Dan Hcu Rumah Sakit Awal Bros Batam. MENARA Ilmu, XII(7), 105-110.

Wijayanti, F. (2017). Hubungan Posisi Duduk dan Lama Duduk Terhadap Kejadian Low Back Pain (LBP) Pada Penjahit Konveksi di Kelurahan Way Halim Bandar Lampung. Skripsi, 57.

Wulandari, N. T., \& Zaidah, L. (2019). Hubungan Usia dan Durasi Lama Duduk dengan Keluhan Nyeri Punggung Bawah pada Pembatik di Kampung Batik Giriloyo. Jurnal Ilmiah Fisioterapi, 2(02), 82-83. Retrieved from http://jurnal.univrab.ac.id/index.php/jif/ar ticle/view/990

Zaman, M. K. (2014). Hubungan Beberapa Faktor Dengan Keluhan Nyeri Punggung Bawah Pada Karyawan Kantor. Jurnal Kesehatan Komunitas, 2(09), 163-167. 